\title{
THE IMPROVEMENT OF IN ISLAMIC LEADERSHIP TOWARDS TEACHER PERFORMANCE WITH COMPETENCY-BASED AND QUALITY OF WORK LIFE
}

\author{
Erni Yuvitasari"
}

\begin{abstract}
* Affiliation:
Fakultas Ekonomi

Unissula Semarang Erniyuvitasari1419@gmail. $\underline{\text { com }}$
\end{abstract}

\section{Abstract :}

The problem in this research is the unimmunity of teacher performance of SD Negeri in Mejobo District Kudus Regency. The purpose of this study is to analyze and to know the influence of Islamic Leadership on Teacher Performance through Teacher Competence and Quality of Work Life of Elementary School Teachers. The population of this research is all elementary school teachers from 3 villages in Mejobo District Kudus Regency as many as 129 people. This study used 100 teachers as a sample with Purposive Random Sampling. Datas were obtained from questionnaires and interviews. Data analysis using SPSS 16.0 and Eviews 9. The result of this research is Islamic Leadership, Teacher Competence, and Quality of Work Life positively influence to Teacher Performance. Based on data analysis only Quality of Work Life on Teacher Performance which has no significant effect. Teacher competence and Quality of Work Life can not be considered as intervening variable in this research.

Keywords: Islamic Leadership, Quality of Work Life, Teacher Competency, and Teacher Performance.

\section{INTRODUCTION}

A teacher is one of the components that play an important role in the development of education. Hermino (2014) says that the key changes as well as build fully qualified human resources there are in the hands of the teacher. The achievement of national development in the education sector is determined by the performance of teachers as educators in the learning process. The performance of teachers into the spotlight and major problems in the improvement of the quality of education.

The attainment of a teacher's performance a teacher in doing tasks and her responsibilities. The performance of the teacher in the school (class) refers to the behavior of teachers in carrying out the work of teacher training, namely teaching (Werang, 2014). Teacher performance is measured from the achievements of teachers in the form of individual 
achievements of the teacher, the contribution in the process of learning, the learning achievements of students, and graduates of these schools generated.

Based on the regulation of the Minister of national education of the Republic of Indonesia (Permendiknas) No. 16 year 2007 about the standard of competence of teachers that includes teacher competency competency competency pedagogic, social, personality, competencies, and competency Professional. Performance assessment of a teacher can be seen and is based on the competence of the fourth. Teacher performance is said to be good if teachers have four such competence in performing her duties.

Optimal performance is the expectation of all parties, but the reality on the ground shows there are still some teachers whose performance is still not optimal. Based on early observations conducted the author in 3 SD State Holy District showed that the performance of primary school teachers is still not optimal. Learning methods used by 11 of the 13 elementary schools in 3 villages (the villages of Japan, Gulang, and Payaman) conventional and teachers still, are still not using modern learning methods (such as the use of electronic media as learning support). A sense of belonging to the teacher morale is also still lacking.

Measurement of competence belonging to teachers is also seen from the results of UKG (test the competency of teachers). UKG is conducted every 5 years. Based on the results of the year 2015 on UKG teachers District of the Holy see that $20 \%$ of the teachers stated still hasn't escaped. It is because of the value of UKG teacher Regency architecture of the Holy 60-70. The value is still below the standard minimum value set out namely by 80 .

The principal must have the ability to manage and empower teachers in order to improve the performance of teachers (Novitasari et al, 2012). Islam religion teaches about leadership that is run by the Prophet Muhammad in leading Muslims. Islamic Leadership also has a very big role in improving the performance of teachers (Hasibuan, 2000 in Wijayanti et al, 2012). Islamic leadership is leadership that is based on the Qur'an and the Hadith that principled that a worker whose ideal makes the Qur'an and the Hadith as the source of their knowledge (Rizqi, 2010 in Aziz et al, 2014).

Quality of work life of teachers is a situation that makes someone a teacher feel satisfied or not satisfied and comfortable or does not use a teacher in carrying out his work. The quality of working life is becoming a major problem that is more than the noteworthy organization (school). The quality of working life is seen to increase the role of the teacher against the school itself (Utomo et al, 2014).

Islamic Leadership) against the performance of teachers (Teacher Performance), which is intervened by the quality of work life (Quality of Work Life) and competence of teachers (Teacher Competency) in the context of the Organization as an educational institution, with the subject research is a primary school teacher in Mejobo Sub District, Kudus.

\section{LITERATURE REVIEW Islamic Leadership}

Leadership according to the Islamic perspective that is an activity guide, guide, guides, and shows the path that is blessed God Almighty that person does as a leader in the organization. Good leadership in Islam is a leadership that has always guided by the Qur'an and the Hadith in the running task and his duty as a leader (Hakim, 2007). 
There are several properties of the leadership of the Prophet Muhammad that could be exemplary: first, Abu-bakr/honesty is the one who has the honesty in being so, uttering the words, as well as acting in the exercise of their responsibilities and duties. Honesty is, in this case, i.e. the leader must have the attitude of honesty in being against a member of the Organization, honest in work means working on her responsibilities as a leader with good and true, and honest in all things especially associated with shared interests.

Second, the mandate/belief that is someone who kept his best about responsibility delegated to him either from God or from his people, so it created a sense of security for all parties. Third, Fathonah/Intelligence that is someone who has the intelligence to deal with and resolve the various problems that come with a good and wise. The principal as leader of the education at school must have emotional intelligence (EQ/Emotional Quotient), intellectual intelligence (IQ/Intelligence Quotient), and spiritual intelligence (SQ/Spiritual Quotient) in running the tunas and her responsibilities as leader of the school. Fourth, Tablighi/Openness that is the attitude of openness shown a leader to its members in decision-making (Wijayanti et al,2012).

The relationship between the Islamic leadership on performance based on the results of research conducted by Wijayanti \& Wajdi (2012) researching on employees BMT Temanggung. Harahap (2016) researching Islamic leadership against the performance of the employees of PT. Bank Syariah Mandiri, Tbk and Mustofiah (2015) that examines employee on Rabbani. The third researcher results found the same i.e. the existence of significant influence among Islamic leadership on performance.

Jensenem \& Sambul (2013) conduct research related to the quality of leadership relationships work life showed a positive and significant influence between the leadership and quality of work life. Those results gave rise to the alleged presence of influence between the Islamic leadership of the quality of work life.

The relationship between the Islamic leadership against competencies appears based on the research results of Nur (2014) on primary school teachers Foundation Pearl Peat. Mahri (2014) and Oktavia (2014) also did a similar study. Findings the researchers showed a positive and significant influence among Islamic leadership against the competency of teachers.

H1: Influential Islamic leadership positively and significantly to the performance of Teachers. H2: Influential Islamic leadership positively and significantly to the quality of work life.

H3: Influential Islamic leadership positively and significantly to the competence of Teachers.

\section{Work Life Quality}

The purpose of the quality of working life is to change and improve the performance of a person so that the relationship between humans, the effectiveness of supporting technologies, and organization make the work experience becomes more attractive and the end result is appropriate with the expected (Luthans, the ultimate in 2006, 2016). The quality of working life is the impact of the effectiveness between people and organizations that are combined with emphasis participation in problem-solving and decision-making especially related to shared interests within an organization (Pamungkas, 2016).

There are some indicators that represent the variable quality of working life, health and wellbeing first it means teachers will feel the comfort and passion in work when gurus 
have a physical and spiritual health and taste well-being. Second, job security, namely teachers feel secure about the future of his career in a job. Third, job satisfaction, that teachers felt the satisfaction of what he obtained in the work environment both physically and non-physical.

Fourth, the development of competence, namely the teacher provided the facilities of the Organization to develop its own competence, such as the holding of a training/training for teachers and seminars that are able to add insight owned by the teacher. The balance between work and life, that the teachers feel have more time left after work. The rest of the remaining time could be used for things that are useful, such as giving extra lessons outside of school hours or tutoring to students.

Some researchers found the existence of a positive and significant influence between the quality of working life on performance, such as Husnawati (2006) on the regional pawn shops Perum employees IV. In addition, Utomo \& Nugroho (2014) and Asis (2014) also doing the same research. The results of different research namely the existence of a positive influence and insignificant discovered by Pamungkas (2016) on the employee's province of Yogyakarta special region BPS.

H4: The quality of working life is a positive and significant effect on the performance of teachers.

\section{Teacher Cometency}

Competence is a person's capability to perform a job based on skills and knowledge as well as supported by the attitude of work required in the job (Posuma, 2013). Teacher's competence is a capability of a teacher in carrying out its work slaughtering activities, behaving or results or achievements can be shown. The quality of education depends greatly on what the teacher is doing (teaching assignment they do) and competence which they have to fulfill this task adequately (Leijen et al, 2017).

In addition, there are also two types of competence that are visible and competency that is hidden. Competence of the visible that is owned by a person of knowledge can be seen by the Organization to determine the tasks/work position that corresponds to that person. Skills competency also can be seen and identified clearly. While a hidden competence i.e. the skills/ abilities that are owned by someone in a particular task. Hidden competence is considered more valuable because it can improve the performance of a person (Mathis dkk, 2001).

Ateacher must meet the four basic competencies according to Permendiknas No. 16.2007. First, the pedagogic Competence, namely the ability of teachers in managing the students using a learning theory and educational principles. Secondly, the competence of personality, i.e., the ability of a teacher in a private being. Third, Social Competence, i.e. the ability of a teacher as an educator in the activities of the society. Fourth, Professional Competence, i.e. the ability of a teacher in the mastery of the learning material. Teachers must also have core competencies, namely a set of knowledge that is able to distinguish the performance of teachers as well as providing the excellence compete in the running of its job compared to the performance of other teachers (Agha, 2012).

Some find the existence of a significant and positive influence on performance competence among teachers such as Posuma (2013) on employee Hospital Ratumbuysang 
Manado. In addition, Sujantiningsih et al (2017) and Ismail (2010) also found the same results. Those results gave rise to allegations as follows:

H5: Teacher's competence and significant positive effect on the performance of teachers.

\section{Teacher Performance}

The performance is a product of someone's work that has been achieved in its work in accordance with the criteria in force in work (Utomo et al, 2014). The teacher's performance is the process of interaction between teachers and students in the learning process, the interaction between the principal as a leader and teacher and students in the learning process as well as between citizens/communities around neighborhood schools.

The performance of the Teachers can be good if it meets the criteria that have been set. Based on the regulation of the Minister of national education of the Republic of Indonesia (Permendiknas) No. 16 year 2007 on standard academic qualification and competence of teachers.

There are five indicators that were able to build a variable performance. First, the quality of work, meaning that the results of the work done the teacher must be in accordance with criteria that have been set. Second, the quantity of work, meaning that the teacher is able to meet the target set by the Labor Government. Third, Timeliness, i.e., teachers must be able to manage time appropriately and well in accordance with the rules in force in work. Fourth, presence, i.e. the teacher must comply with all the rules relating to the presence of the teacher at work. Fifth, the ability to work together, i.e. a teacher must have a sense of solidarity and willing to cooperate with others in completing tasks and obligations so that the objectives of the organization which has been set can be achieved (Mathis et al, 2001).

In addition, there are several factors which are able to affect the performance of the person. First, the individual factors related to the skill, motivation, commitment, and others. Second, the leadership factor related to the quality of the support and guidance provided by the leadership, Manager, or Chairman of the working group. Third, factor groups/colleagues with regard to the quality of the support provided by work colleagues. Fourth, system factors associated with the system/method of working there and the facilities provided by the organization. The fifth Factor, the situation with regard to pressure and environmental change, both internal and external environment (Amstrong, 1998 in Asis, 2014).

\section{RESEARCH METHODOLOGY}

Object of this research is the primary teachers of 3 villages in district Mejobo District that consists of 13 elementary schools of the country. The overall population of the country primary school teachers from 3 villages (the villages of Japan, Gulang, and Payaman) in district Mejobo of 129 teachers. Respondents used in the study of 100 teachers with the samplingtaking technique used was Purposive Random Sampling. Characteristics of the sample that will be used in this research include Teacher tenure status taken employees to remain, the principal and teachers must be Muslim, minimum 2 years work experience, age, and educational year 22-60 last minimum D4. 
The independent variable in this study is the Islamic Leadership variables. The indicators used in this variable there are four, namely Honesty, trust, intelligence, and openness. Statement questionnaire in this variable is measured using a Likert scale.

Intervening variables in this study is twofold. The first is the variable quality of work life that consists of five indicators, namely, health and welfare, job security, job satisfaction, competency development, and the balance between life and work. The measurement of the questionnaire in this variable using the Likert scale.

The second intervening variables in this study is the competence of the teacher. The indicators used in this variable there are four, namely pedagogic competence, social competence, personality, competencies, professional competence. Measurements are used namely Likert scale. The dependent variable in this study was the performance of teachers. Performance indicators teacher consists of five i.e., quality of work, the quantity of work, attendance, punctuality, and the ability to cooperate. Statement of the research questionnaire will be measured using the Likert scale.

\section{RESULT AND DISCUSSION \\ Test validity and Reliability}

Testing the validity and reliability of this research aided software SPSS 16.0. the validity of the test results of this research have the good value that is, the value of $r$ count of all the indicator variables is greater than $r$ table of $1.966(n=100)$. Therefore, all indicators in this study were declared valid.

Test reliability can be seen from Alpha Cronbach's value of each variable research. Cronbach's Alpha value $\mathrm{X}=0.758 ; \mathrm{Y} 1=0.772 ; \mathrm{Y} 2=0.771 ; \mathrm{Y} 3=0.761$. Those values greater than 0.6 so that the data of this research revealed reliability.

\section{A Classic Assumption Test}

Est your Multikolinieritas with the help of SPSS 16.0. Results of research indicates that output value of VIF (Variance Inflation Factor) for all the variables $(\mathrm{X}=1,221$; Y1=1,158; Y2= $1,065)$ less than $10(\mathrm{VIF}<10)$ with sign. 5\% $(0,05)$. Sedangkan nilai tolerance model regresi I $(X=$ 2,261; $\mathrm{Y} 1=0,987$; $\mathrm{Y} 2=3,099$ ), regression II model is 3,929, regression III is 2,519 bigger than $0,10(>0,10)$. $t$ shows that this research does not occur multikolinieritas symptoms in all three of these regression models. It means not found the presence of correlation is high inthis study.

This helped linearity testing using software Eviews 9. result of linearity this indicates that the output value of the Prob. F calculate the regression model 1 for 0.4657 ; the regression model II of 0.7340; as well as regression model III of 0.2975 . The value is greater than 0.05 $(0.05>)$ so that the regression models revealed the third meet the assumption linearity. It means the regression model used in this study is considered it is correct.

Autocorrelation test rules adapted to the method DWtest (Durbin-Watson test). If the value of the DW lies between the value of dU (upper limit) with (4-dU) regression model does not occur then the autocorrelation. The regression model means there is no error between the previous period data with data in the next period. The autocorrelation test output results shown in Table 1 shows that the regression model the third there is no autocorrelation. 
Table 2. Autocorrelation

\begin{tabular}{|c|c|c|c|c|c|}
\hline $\begin{array}{l}\text { Model } \\
\text { Regresi }\end{array}$ & dL & dU & (4-dU) & DW & Ket. \\
\hline 1 & 1,6131 & 1,7364 & 2,2636 & 2,094 & Lolos \\
\hline 2 & 1,6540 & 1,6944 & 2,3460 & 1,992 & Lolos \\
\hline 3 & 1,6540 & 1,6944 & 2,3460 & 2,1660 & Lolos \\
\hline
\end{tabular}

Source: Processed Primary Data, 2017.

Heteroscedasticity test using the software SPSS 16.0. The results of the research output of this third regression model it is known that this research does not occur heteroscedasticity. It is because the value of the probability values $>$ alpha $(0.05)$ so that the models used for forecasting (estimation). Test of normality is assisted with the software SPSS 16.0. results analysis test of normality indicates that residual value curve standardized to be normal because the value spread Asymp. Sign. (2-tailed) $=0.285>$ alpha values (0.05). The data suggested that residual values are normally distributed so that this research has revealed models meet the assumptions of normality.

\section{Test-Path Analysis}

This research uses statistical analysis method of path analysis (Path Analysis Method). Researchers used path analysis to identify whether the quality of working life (Y1) and the competency of teachers (Y2) capable of intervening variables considered in this study. Path analysis testing can be seen in the picture below.

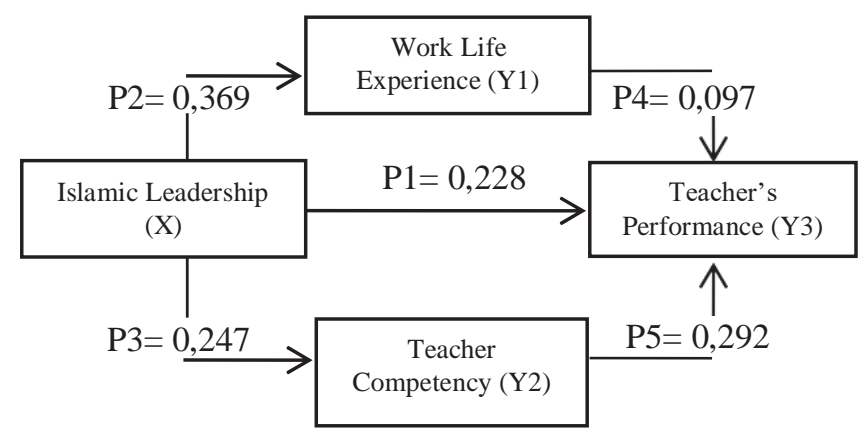

Figure 2. Path Analysis

Description: $\mathrm{P} 1=$ coefficient of influence between the $\mathrm{X}$ and the $\mathrm{Y} 3 ; \mathrm{P} 2=$ the coefficient of influence between $\mathrm{X}$ and $\mathrm{Y} 1 ; \mathrm{P} 3=$ the coefficient of influence between $\mathrm{X}$ and $\mathrm{Y} 2$; $\mathrm{P} 4=$ coefficient of influence between Y1 and Y3; and P5 = coefficient of influence between Y2 and Y3. 
Table 3. Path Analysis Result

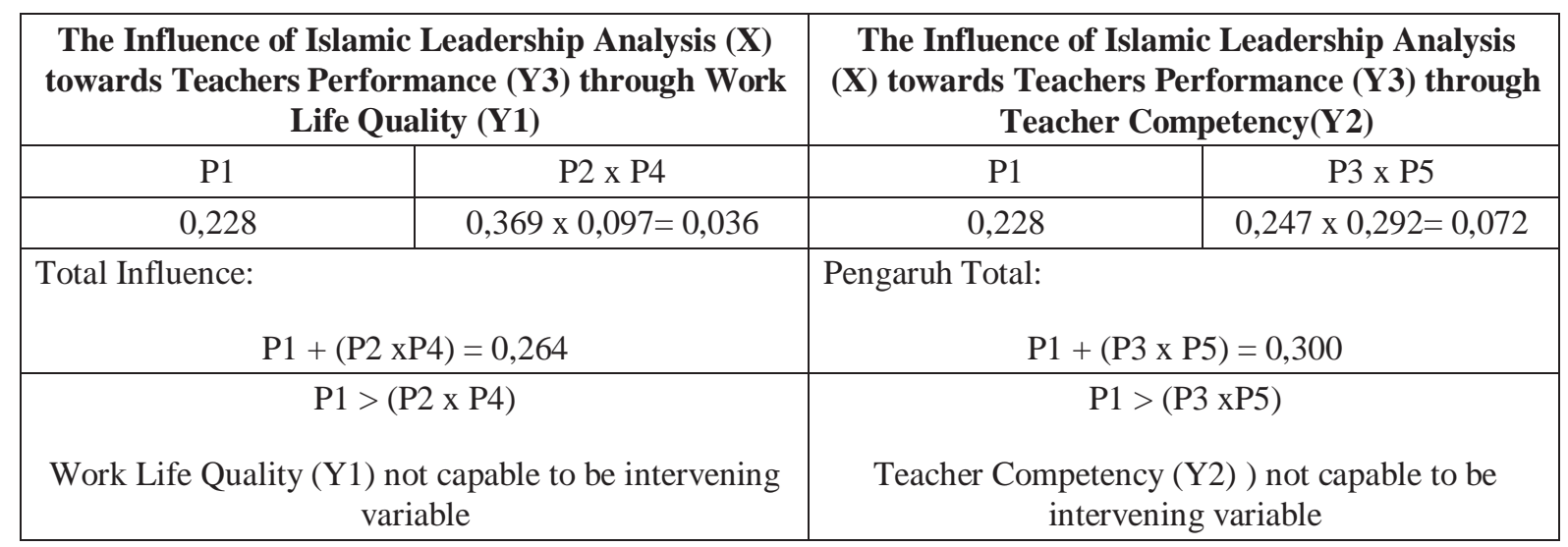

Source: Processed Primary Data, 2017

\section{Multiple Linear Regression analysis to test and test Hypotheses}

Multiple linear regression analysis of the test used to measure the intensity of the relationship between two variables. The regression model in this study there were three, where the output results Furthermore can be seen in table 3. This regression assisted data processing software SPSS 16.0.

A test of the hypothesis test of significance $F$ aiming for the regression coefficient of the free variable (X, Y1, and Y2) jointly against variables bound (Y3). Output results of this research can be found in table 3 . There are three regression models conducted testing hypothesis f. results show that third regression model research indicates significant results. It means that there is a significant relationship between variables together in each regression model.

Test hypotheses $t$ test how significant the purpose for the relationship between the dependent variable against the independent variable. The five hypotheses that are formed in the research companies do test data processing Results t. the t-test can be seen in table 3. one of the five hypotheses are formed in this study showed a rejection of the hypothesis in hypothesis four. The fourth hypothesis assumed a relationship between the quality of work life against the performance of teachers, where results found shows that there is a positive influence and not significant. While the four other hypotheses showed positive and significant results. 
Table 4. A summary of the results of the calculations and data processing

\begin{tabular}{|c|c|c|c|c|c|c|c|c|c|c|}
\hline $\begin{array}{c}\text { Regression } \\
\text { Model }\end{array}$ & $\begin{array}{l}\text { Stand. } \\
\text { Coef. }\end{array}$ & $\mathbf{F}_{\text {hitung }}$ & Sig. F & $\mathbf{R}$ & $\mathbf{R}^{2}$ & Note. & Hypothesis & $\mathbf{T}_{\text {count }}$ & Sign. $t$ & Note. \\
\hline $\begin{array}{l}\text { Regression I : } \\
\text { Constant } \\
\text { Islamic } \\
\text { Leadership } \\
\text { (X) } \\
\text { Work Life } \\
\text { Experience } \\
\text { (Y1) } \\
\text { Teacher } \\
\text { Competency } \\
\text { (Y2) }\end{array}$ & 0,097 & 8,052 & 0,000 & 0,448 & 0,176 & Sign. & $\begin{array}{c}\text { H1 } \\
(\mathrm{X} \rightarrow \mathrm{Y} 3)\end{array}$ & 2,261 & 0,026 & $\begin{array}{l}\text { Positive } \\
\text { and } \\
\text { Sign. }\end{array}$ \\
\hline \multicolumn{7}{|c|}{$\begin{array}{c}\text { The Equity Linier I regression Model: } \\
\qquad 3=b_{1} X+b_{2} Y 1+b_{3} Y 2+e \\
Y 3=0,228 X+0,097 \mathrm{Y} 1+0,292 \text { Y2 }\end{array}$} & $\begin{array}{c}\text { H2 } \\
(\mathrm{X} \rightarrow \mathrm{Y} 1)\end{array}$ & 3,929 & 0,000 & $\begin{array}{l}\text { Positive } \\
\text { and } \\
\text { Sign }\end{array}$ \\
\hline $\begin{array}{l}\text { Regression } \\
\text { II : } \\
\text { Constant } \\
\text { Islamic } \\
\text { Leadership } \\
\text { (X) }\end{array}$ & 0,369 & 15,439 & 0,000 & 0,369 & 0,136 & Sign. & $\begin{array}{c}\text { H3 } \\
(\mathrm{X} \rightarrow \mathrm{Y} 2)\end{array}$ & 2,519 & 0,013 & $\begin{array}{l}\text { Positive } \\
\text { and } \\
\text { Sign }\end{array}$ \\
\hline \multicolumn{7}{|c|}{$\begin{array}{l}\text { The Equitry of Linier II regression Model: } \\
\qquad \mathrm{Y} 1=\mathrm{b}_{1} \mathbf{X}+\mathrm{e}\end{array}$} & $\begin{array}{c}\text { H4 } \\
(\mathrm{Y} 1 \rightarrow \mathrm{Y} 3)\end{array}$ & 0,987 & 0,326 & $\begin{array}{l}\text { Positive } \\
\text { and no } \\
\text { Sign. }\end{array}$ \\
\hline $\begin{array}{l}\text { Regression } \\
\text { III: } \\
\text { Constant } \\
\text { Islamic } \\
\text { Leadership } \\
\text { (X) }\end{array}$ & 0,247 & 6,345 & 0,013 & 0,247 & 0,061 & Sign. & $\begin{array}{c}\text { H5 } \\
(\mathrm{Y} 2 \rightarrow \mathrm{Y} 3)\end{array}$ & 3,099 & 0,003 & $\begin{array}{l}\text { Positive } \\
\text { and } \\
\text { Sign }\end{array}$ \\
\hline & Equitry & $\begin{array}{r}\text { of Linie } \\
\text { Y2 = } \\
\text { Y2 = } 0\end{array}$ & $\begin{array}{l}\text { III reg } \\
{ }_{1} \mathrm{X}+\mathrm{e} \\
47 \mathrm{X}+\end{array}$ & ession $\mathrm{N}$ & odel: & & & & & \\
\hline
\end{tabular}

Source: Processed Primary Data, 2017. 


\section{Islamic Leadership Influence On Performance Of Teachers}

Table 4 describes the results of a test of hypothesis 1 suggests that $t$ is no positive and significant influence among Islamic leadership (X) against the performance of teachers (Y3). It is attested from the results of the comparison t count (2.261) > t table (1.988) and value sign. $\mathrm{t}(0.026)<$ sign. Alpha (0.05). It means teachers will increase performance if the application of the Islamic leadership style do the principals have also improved. The relationship will strengthen research results Mustofiah (2015) who discovered the existence of a positive and significant influence among Islamic leadership against the performance of teachers.

The relationships between these variables are built based on the relationship of each indicator against the Islamic leadership performance guru. Islamic leadership indicators that include the attitude of honesty principals, Trustees/trust owned by the Headmaster in the lead, intelligence, and an attitude of openness towards the School's headteacher. Performance indicators teacher include the quality of work, work quantity, timeliness of teachers in carrying out tasks and her responsibilities as an educator, the presence of the teacher, as well as capabilities in collaboration between colleagues and Principal Correlation. between the Islamic leadership against the performance of primary school teachers of the country built in the study considered to be still quite namely of the first Hypothesis 0,228 . in this study stated acceptable.

\section{The Influence Of The Islamic Leadership Of The Quality Of Work Life}

The second hypothesis to suspect a positive and significant influence between the Islamic leadership of the quality of work life. Table 4 describes the results of at indicates that the second hypothesis is accepted, this means that there is a positive and significant influence between the Islamic leadership of the quality of work life. It is evident from the results of the count of $\mathrm{t} 3.929>\mathrm{t}$ table of 1.988 and signs $\mathrm{t}(0.000)<\operatorname{sign}$. alpha $(0.05)$.

The results of the testing research data show that there is a positive and significant influence among Islamic Leadership with the quality of work life, so hypothesis 2 is acceptable. The implication, if the intelligence of a school principal is increased it will improve the health and well-being of the perceived a teacher. If the principal is increased openness attitude in the work environment, it will be a good influence against the job security and development of the competence of a teacher. An increased sense of trust Principal is also able to enhance the sense of job satisfaction against the teachers. In addition, the attitude of honesty high school principal will improve the balance between work and life for a teacher. This research concluded that hypothesis 2 Islamic Leadership relationships related to the quality of work life are acceptable.

\section{The Influence Of Teacher Competence Against The Islamic Leadership}

The third hypothesis to suspect a positive and significant influence in this research. Based on the results of the test $t$ in table 4 show that the third hypothesis is accepted. This means that this study found positive and significant influence among Islamic leadership against the competency of teachers. The proof that the value $t$ calculate $(2.519)>t$ table (1.988) and value sign. $\mathrm{t}(0.013)$ value < sign. Alpha (0.05) which concluded the accepted hypothesis.

Islamic leadership and competence of teachers have a positive influence on one another. If a principal has a high level of honesty then the competence of personality of teachers is 
expected to increase. It is due to the presence of a sense of AWE that arises from within the teacher to the principal. The head of the school that has a high level of trust to the teachers is expected to increase the competence of teachers in professionalism. High intelligence who owned the principal expected to help teachers to improve the competence of pedagogic way exchange thoughts and opinions between one another. The attitude of openness is high from the principal will be able to improve the social competence of the teacher. The harmonious relationship will be interwoven between principals with teachers as well as to students and caregivers.

The implications of the existing Teacher Competencies will increase if a gets a boost and support to make changes that better. The impetus for change there are two, namely encouragement of the outer and inner self. One example of a push from the outside that is the attitude and application of the leadership style of the Islamic school principal.

\section{The Influence Of Quality Of Working Life On Performance Guru}

The fourth hypothesis to suspect a positive and significant influence between the quality of work life against the performance of teachers. T-test results in table 4 that concludes the fourth hypothesis in this study was rejected.

Pruijt (2003) explains that the General relationship between the quality of life research Work on performance shows positive results. Positive influence that is, if the perceived worklife Quality of teachers improved it will improve the performance of the Teacher. Relationships between the variables can be seen from the relationship between indicators of the variable. The implication, if an elementary school teacher earns high health and welfare then the teachers feel excited about work every day so that the presence of the teachers will be increased. If the teacher's Competency development increased then the quality of work and ability to cooperate the teachers will increase.

The results of this study concluded that there is no significant influence between the quality of working life with the performance of teachers. These Results have in common with the results obtained by Pamungkas (2016) against employees of the special province of BPS Yogyakarta. This can be understood because of a teacher working in SD Land being required for a high-performing always in any condition. These claims are considered the responsibility of the State as SD form institutions engaged in community service, namely educational services.

Teachers should be able to afford himself to any high-performance work environment conditions are perceived. Although institutional basis under the auspices of the Ministry of education and culture (Kemendikbud) continues to seek improved quality of work life of a teacher, the teacher has had a high sense of self to stay and continue to strive to improve its performance as good as possible. The results of this research are thus to make proud all primary school teachers the country because under no circumstances a teacher who served as an educator and has the instincts of an educator to keep high-performing. However, the pride shown should not be too exaggerated because the effect is thus able to make the teacher's Performance declined. So, it can be concluded that the hypothesis in this study 4 in decline. 


\section{The Influence Of Teacher Competence Against The Performance Of Teachers}

The fifth suspect a hypothesis of positive and significant influence between the competence of the teacher against teacher performance. T-test results in table 4 that concludes the fifth accepted hypothesis in this study. It is evidenced from the data processing results shows t count (3.099) > t table (1.988) and value sign. $t$ (0.003) value < sign. Alphas (0.000).

Results have in common with the real conditions in the field. Based on the results of research in the form of a questionnaire and interviews found the same conditions between existing hypothesis with conditions directly in the field. For example, if a teacher personality competence has increased, then the quality of work will increase. Competence of personality sense of self-awareness in managing their time will also experience increased, such as timeliness in carrying out its duties and responsibilities, as well as the presence of the time must be in accordance with the applicable rules. In addition, the competence of teacher professionalism should be applied as well as possible, and should always be improved. It will provide a positive impact on the quality and quantity of work of a teacher in an organization.

In addition, a teacher in the era of globalization was also required to increase social competence in their environment. It aims to increase the sense of empathy and concern for fellow good job surroundings, family environment or the environment of the community. For example, a teacher gave his students to spare time for sharing and communicating with either academic or non-related difficulties often encountered academic disciple. In addition, a teacher makes a group communication with my fellow co-workers. It aims to increase the sense of solidarity, cooperation, and a sense of family against colleagues and Principals. teachers should also be able to establish a polite communication and well against the surrounding communities and caregivers. Communication is entwined with the good will be able to improve the quality of work of teachers in communicating and relate well with fellow human beings on this earth.

\section{CONCLUSION}

Islamic leadership has a positive and significant influence against the variable performance of the Teachers in this study. Application of the leadership style of Islamic principals will encourage the increased performance that produced teachers in that school. Quality of work life of teachers and the perceived competence of State-owned primary school teachers in this study showed very good results. The results of this study in accordance with the real conditions that the teacher is doing his job as an educator in sincere regardless of perceived work-life quality such as, the condition itself and the surrounding work environment conditions. Teachers should also be given help in motivation, and infrastructure to increase competency. The results of this study demonstrate how to resolve the main problems of the existing related still suboptimal performance of State ELEMENTARY SCHOOL teachers in district Mejobo District, namely the existence of a Holy applying Islamic school principal Leadership. It is in accordance with the results of this study in which the existence of direct influence is high between application of Islamic school principal leadership style will be able to improve the performance of the State primary school teachers. 


\section{REFERENCES}

Agha, S., Alrubaiee, L., Jamhour, M. (2012), Effect of Core Competence on Competitive Advantage and Organizational Performance, International Journal of Business and Management, 7 (1), 192-204.

Arifin, N. (2012), Analisis Kualitas Kehidupan Kerja, Kinerja, dan Kepuasan Kerja pada CV. Duta Senenan Jepara, Jurnal Economia, 6 (1), 11-21.

Arthawan, K. J., Mujiati, N. W. (2014), Pengaruh Gaya Kepemimpinan Transformasional dan Kepuasan Kerja Terhadap Kinerja Karyawan pada LPD Kesiman di Denpasar, E-Jurnal Manajemen Unu, 6 (3), 221-1247.

Asiz, A. (2014), Pengaruh Kualitas Kerja Pegawai Terhadap Kinerja Pegawai di Kantor Kecamatan Bontang Selatan, eJournal Ilmu Pemerintahan, 2 (3), 2640-2649.

Aziz, R., Shofawati, A. (2014), Pengaruh Kepemimpinan Islami dan Budaya Organisasi Islami Terhadap Motivasi Kerja Islami pada UMKM Kulit di Magetan, JESTT, 1 (6), 393-409.

Bana, A. (2016). Pengaruh Kepemimpinan Transformasional dan Lingkungan Kerja Fisik Terhadap Kinerja Pegawai Dengan Motivasi Kerja Sebagai Variabel Pemediasi (Studi pada Organisasi Daerah Air Minum (PDAM) Kota Kendari), Jurnal Bisnis dan Manajemen, 3 (1), 1-16.

Darsana, I. W., Putra, M. S. (2017), Pengaruh Keadilan Organisasional, Kepemimpinan Transformasional, dan Kepuasan Kerja Terhadap Komitmen Organisasional pada Karyawan Ayodya Resort, E-Jurnal Manajemen Unud, 6 (1), 146-175.

Fakultas Ekonomi. (2015), Buku Pedoman Penulisan Praskripsi, Skripsi, Artikel Ilmiah, Semarang: Universitas Islam Sultan Agung Semarang.

Ghozali, I. (2011), Aplikasi Analisis Multivariate Dengan Program IBM SPSS 19 (edisi kelima), Semarang: Universitas Diponegoro.

Gibson, J. (2003). Fisiologi dan Anatomi Modern untuk Perawat, Jakarta: Penerbit Buku Kedokteran EGC.

Hakim, A. (2007).Kepemimpinan Islami, Semarang: Unissula Press.

Handoko, T. H. (2009), Manajemen. Edisi Kedua, Yogyakarta : BPFE-Yogyakarta.

Harahap, S. (2016), Pengaruh Kepemimpinan Islami dan Motivasi Kerja Terhadap Kinerja Karyawan pada PT. Bank Syariah Mandiri, Tbk Kantor Cabang Pembantu Sukaramai Medan, HUMAN FALAH,3 (2), 253-270.

Hermino, A. (2014), Kepemimpinan Pendidikan di Era Globalisasi, Yogyakarta: Pustaka Pelajar.

Husnawati, A. (2006), Analisis Pengaruh Kualitas Kehidupan Kerja Terhadap Kinerja Karyawan dengan Komitmen dan Kepuasan Kerja Sebagai Intervening Variabel, Tesis Magister Manajemen, Universitas Diponegoro, Semarang. 
I.D.K.R. Ardiana, L., Subaedi. (2010). Kompetensi SDM UKM dan Pengaruhnya Terhadap Kinerja UKM di Surabaya, Jurnal Manajemen dan Kewirausahaan, 12 (1), 42-55.

Ismail, M. I. (2010), Kinerja dan Kompetensi Guru dalam Pembelajaran, Lentera Pendidikan, $13(1), 44-63$.

Jensenem, M. B., Sambul, S. M. (2013), Pengaruh Gaya Kepemimpinan Terhadap Kualitas Kehidupan Kerja Karyawan Perum Pegadaian Kantor Pusat Wilayah V Manado, JIA, 9 (1), 1-5.

Kaihatu, T. S., Rini, W. A. (2007), Kepemimpinan Transformasional dan Pengaruhnya Terhadap Kepuasan atas Kualitas Kehidupan Kerja, Komitmen Organisasi, dan Perilaku Ekstra Peran: Studi pada Guru - Guru SMU di Kota Surabaya, Jurnal Manajemen dan Kewirausahan, 98 (1), 49-61.

Leijen, A., Slof, B., et al. (2017), Performance-Based Competency Requirements for Student Teachers and How to Assess Them, International Journal of Information and Education Technology, 7 (3), 190-194.

Mahri, A. J. W. (2014), Kepemimpinan Kepala Sekolah, Pengaruhnya Terhadap Kompetensi, Motivasi dan Kepuasan Kerja Guru serta Implikasinya pada Kinerja Guru, Kontigensi, $2(1), 39-54$.

Mangkunegara, A. P. (2009), Manajemen Sumber Daya Manusia, Bandung: PT. Remaja Rosdakarya.

Mathis, R. L., Jackson, J. H. (2001), Manajemen Sumber Daya Manusia, Jakarta: Salemba Empat .

(2006), Manajemen Sumber Daya Manusia, Jakarta: Salemba Empat.

Musthofiah, S. (2015), Pengaruh Kepemimpinan Islami Terhadap Kinerja Karyawan pada Rabbani Semarang,Skripsi, Universitas Islam Negeri Walisongo, Semarang.

Novitasari, A., Wahyudin, A., Setiyani, R. (2012), Pengaruh Kepemimpinan Kepala Sekola, Lingkungan Kerja, Pendidikan, dan Pelatihan Terhadap Kinerja Guru, Economic Education Analysis Journal, 1 (2), 1-6.

Nur, A. A. (2014), Meningkatkan Kompetensi Pedagogik Guru di SD Yayasan Mutiara Gambut, Bahana Manajemen Pendidikan, 2 (1), 65-831.

Oktavia, R. (2014), Kompetensi Kewirausahaan Kepala Sekolah pada Sekolah Menengah Pertama Negeri di Kecamatan Hiliran Gumanti Kabupaten Solok, Bahana Manajemen Pendidikan, 2 (1), 596-831.

Pamungkas, Y.(2016), Pengaruh Kualitas Kehidupan Kerja Terhadap Kinerja dengan Kepuasan dan Kepuasan Sebagai Variabel Intervening, JBTI, 7 (2), 221-250.

Posuma, C. O. (2013), Kompetensi, Kompensasi, dan Kepemimpinan Pengaruhnya Terhadap Kinerja Karayawan pada Rumah Sakit Ratumbuysang Manado, Jurnal EMBA, 1 (4), 646-656. 
PDSP KEMDIKBUD.(2017). Data Guru SD Tiap Desa di Kecamatan Mejobo Kabuapten Kudus, Dinas Pendidikan Provinsi Jawa Tengah, Jawa Tengah.

Reddy \& Redy. (2010), Quality of Work Life of Employee: Emerging Dimensions, Asian Journal of Management Research. Integrated Publishing Association, 11, 824-839.

Sanusi, A. (2011), Metodologi Penelitian Bisnis, Jakarta : Salemba Empat.

Sujantiningsih, N. K., Sujana, E., Sulindawati, N. L. (2017), Pengaruh Kompetensi Sumber Daya Manusia, Gaya Kepemimpinan, dan Motivasi kerja Terhadap Kinerja Hotel Berbintang di Kawasan Lovina Singaraja, e-Journal S1 Ak, 7 (1), 1-12.

Utomo, H. S., Nugroho, M. (2014), Model Peningkatan Kinerja Karyawan Melalui Kualitas Kehidupan Kerja, Ekobis, 15.(1), 31-50.

Tu'u, T. (2004), Peran Disiplin Pada Perilaku dan Prestasi Siswa< Jakarta: Persada.

Wahjosumidjo.(2010), Kepemimpinan Kepala Sekolah. Jakarta: Raja Grafindo Persada.

Werang, B. R. (2014), Pengaruh Kepemimpinan Transformasional Kepala Sekolah, Moral Kerja, dan Kepuasan Kerja Terhadap Kinerja Guru SDN di Kota Merauke, Cakrawala Pendidikan., 23 (1), 128-137

Wijayanti, R., Wajdi, F. (2012), Pengaruh Kepemimpinan Islami, Motivasi, dan Kepuasan Kerja Terhadap Kinerja Karyawan dengan Lama Kerja Sebagai Variabel Moderating, Daya Saing, 13 (2), 108115. 